\title{
Membangun Proxy Server Cv Global Max Menggunakan Sistem Operasi Linux Blankon 6.0 Ombilin Sebagai Manajemen Akses Jaringan
}

\author{
Wahyudi, Keukeu Rohendi, Ilham Eka Putra \\ Sistem Informasi, STMIK Indonesia Padang \\ email: wahyudisy@yahoo.com
}

http://dx.doi.org/10.22202/jei.2014.v1i1.1441

\begin{abstract}
The computer network is a collection of computers that are connected to each other and work automatically. It can affect the stability of the internet connection that is the amount of bandwidth used and how effective the network bandwidth can be utilized. Bandwidth is a measure of the amount of information that can flow from one place to another within a certain time. Proxy server allows the administrator to limit bandwidth usage can be used by the user and also limit the bandwidth that can be used by a particular file type. One type of method of managing bandwidth using squid. Squid is a caching application GPL (GNU Public License) and an implementation of a proxy server that can store objects in the cache. In testing the download and upload can be seen that the system is able to divide bandwidth fairly to all users. To test the content filtering system using two methods, namely filtering with squid and linux BlankonOmbilin. Then the system is also blocking social media access during business hours so that the learning process can proceed smoothly.
\end{abstract}

Keywords: computer networks, bandwidth, squid, blankon 6.0 ombilin, proxy server

\section{PENDAHULUAN}

Perkembangan jumlah pengguna Teknologi Informasi utamanya Internet saat ini sangat pesat, hal ini disebabkan oleh semakin banyaknya masyarakat yang menyebarkan informasinya melalui internet. Mulai dari informasi sederhana hingga kompleks, informasi bersifat individu maupun organisasi. Selain itu sebagian masyarakat menjadikan internet sebagai kebutuhan pokok, dan dari hari ke hari jumlahnya cenderung meningkat.

Perkembangan jumlah pengguna tersebut umumnya tidak diikuti oleh penambahan bandwidth yang sesuai, sehingga sering timbul masalah terkait dengan kecepatan akses untuk mendapatkan layanan melalui internet. Selain itu umumnya masyarakat kurang memperhatikan keamanan sistem digunakan agar terhindar dari serangan.[1]
Kontrol akses sangat diperlukan agar penyalahgunaan sumber daya pada jaringan tersebut tidak pernah terjadi. Sistem keamanan berupa Proxy Server dan Firewall dapat digunakan untuk mengatur lalu lintas jaringan dan hak akses setiap klien serta dengan mudah melakukan perhitungan pemakaian koneksi ke internet oleh setiap klien.[2]

Proxy Server adalah sebuah komputer server atau program komputer yang dapat bertindak sebagai komputer lainnya untuk melakukan request terhadap content dari internet atau intranet. Proxy server bertindak sebagai gateway terhadap dunia internet untuk setiap komputer klien. Proxy server tidak terlihat oleh komputer klienseorang pengguna yang berinteraksi dengan internet melalui sebuah proxy server tidak akan mengetahui bahwa sebuah proxy server sedang menangani request yang sedang dilakukannya. Web server yang menerima request dari proxy server akan menginterpretasikan request- 
request tersebut seolah-olah request itu datang secara langsung dari komputer klien, bukan dari proxy server.[3]

BlankOn Linux pertama kali dikembangkan oleh YPLI pada tahun 2004 dengan nama kode "Bianglala". Pada saat itu, BlankOn merupakan turunan dari distro Fedora Core 3. Namun, rilis BlankOn pada saat itu berakhir sampai versi 1.1 dan akhirnya mati suri.

Pada tahun 2007, pengembangan BlankOn Linux mulai dibangkitkan kembali oleh YPLI. BlankOn Linux yang sebelumnya diturunkan dari Fedora Core kini diganti menjadi Ubuntu. BlankOn Linux direncanakan akan dirilis sesuai dengan siklus rilis Ubuntu, yaitu setiap 6 bulan sekali atau 2 kali setahun. Setiap rilis BlankOn Linux akan diberi tema dan ciri khas yang berbeda sesuai dengan budaya yang ada di Indonesia. [4]

\section{Perumusan Masalah}

Untuk memperjelas permasalahan yang akan diteliti, maka masalah tersebut dirumuskan sebagai berikut:

1. Bagaimana membangun proxy server CV Global Max menggunakan sistem operasi linux blankon

2. Bagaimana meminimalisasi serangan server

3. Bagaimana manajemen jaringan lalu lintas data bandwith internet

\subsection{Tujuan Penelitian}

Penelitian ini secara umum bertujuan menganalisa sejauhmana fungsi dan arsitektur yang tepat yaitu membangun proxy server di CV Global Max. Adapun objektif dari penelitian yang akan dilaksanakan sebagai berikut:

1. Menerapkan dan mempermudah membangun proxy server dari instalasi dan pemasangan linux blankOn

2. Meminimalisir serangan virus, worm, spyware dan DDOS
3. Manajemen jaringan dan lalu lintas internet Penghematan bandwidth dan peningkatan kecepatan

\section{KAJIAN LITERATUR DAN PEGEMBANGAN HIPOTESIS}

\subsection{Linux}

Linux merupakan sistem operasi UNIX-like yang menggunakan kernel linux. Perkembangan linux dilakukan oleh Linus Benedict Tovalds, Universitas Helsinki Finlandia sebagai proyek hobi. Seluruh kode sumber linux termasuk kernel, device driver, pustaka, program dan perangkat pengembangan disebarkan secara bebas dengan lisensi GNU GPL (General Public License). Nama Linux sendiri diambil dari kernel Linuxyang ditulis oleh Linu, namun pendiri Free software Foundation, Richard Stallman (pencetus GNU Project) lebih memilih menyebutnya GNU/Linux. [5]

Linux tidak memuat kode UNIX, melainkan ditulis ulang berdasarkan standar POSIX. Linus mengelola kernel, menerima penambahan dan modifikasi dari banyak orang di seluruh dunia. Linus menerapkan kendali kualitas dan menambahkan semua kode baru ke kernel. Linux telah di-port ke banyak platform antara lain intel x86, alpha axp, MIPS, sparc dan power pc. Sekitar 95\% kode sumber kernel adalah sama untuk semua platform perangkat keras.[6]

\subsection{Blankon Linux}

Merupakan sebuah distribusi turunan Ubuntu yang dikembangkan Yayasan Penggerak Linux Indonesia dan KPLI. Yang membuat berbeda Ubuntu dan BlankOn adalah, BlankOn dikembangkan dengan memasukkan paket-paket yang sesuai untuk masyarakat Indonesia, yaitu paket-paket yang ringan (karena ekonomi masyarakat Indonesia lemah, jadi sebagian besar komputer-komputernya tidak terlalu bagus). BlankOn menyediakan semua lib multimedia 
sehingga langsung bisa memutar file-file multimedia. BlankOn benar-benar punya cita rasa Indonesia dan dibanggakan komunitas Linux Indonesia.[7]

Pengembangan BlankOn bukan semata-mata ingin membuat distribusi Linux baru, namun lebih dimotivasi oleh keinginan untuk meningkatkan kualitas dan kuantitas dalam kemampuan pengembangan perangkat lunak bebas/terbuka, yang pada hakikatnya merupakan salah ciri khas bangsa Indonesia yang memiliki semangat bergotong-royong. Tim pengembang BlankOn percaya bahwa bangsa Indonesia mampu dan tidak kalah dengan bangsabangsa lain di dunia dan oleh karena itu aktif mengundang siapa pun yang berminat dan memiliki semangat yang sama untuk bergabung dalam pengembangan BlankOn.

\subsection{Proxy Server}

Proxy server adalah sebuah komputer atau kumpulan komputer yang diletakkan sebagai pelayanan pelanggan (yang selanjutnya disebut client) yang meminta pelayanan data baik dari pusat komputer (yang selanjutnya disebut dengan Server) ataupun dokumen web. Proxy server melayani komunikasi antara client dan server yang dituju tanpa merubah permintaan ataupun balasan. Sebuah proxy server dapat melakukan penyaringan permintaan berdasarkan aturan-aturan yang telah dibuat dan memungkinkan komunikasi hanya jika permintaan diijinkan berdasarkan pada aturan-aturan yang telah dibuat dan disetujui dalam jaringan komputer. Aturan-aturan yang dibuat biasanya berdasarkan alamat protokol internet (yang selanjutnya disebut IP Address) dari client atau server tujuan, protokol, jenis isi sebuah dokumen web, jenis isi web, dan lain-lainnya.[8]

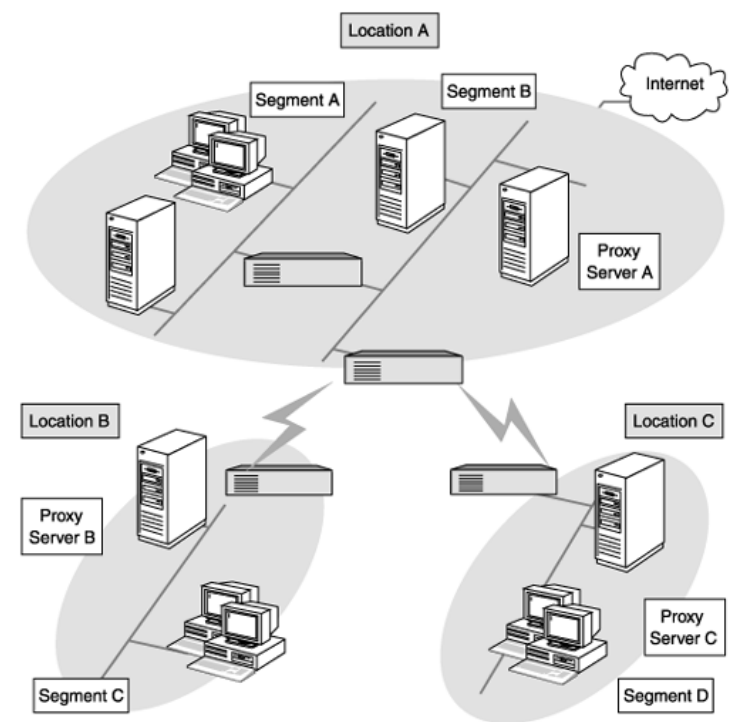

Gambar 1. Arsitektur Desain Proxy Server pada sebuah jaringan computer [9]

Proxy server bekerja sebagai perantara antara website dan web browser. Web browser dikonfigurasi untuk menggunakan proxy server tidak mengakses situs secara langsung diinternet. Proxy server bertindak sebagai perantara antara dua buah jaringan, dimana salah satu dari jaringan tersebut bertindak sebagai internet umum (yang selanjutnya disebut dengan public internet) sedangkan yang lainnya bertindak sebagai komputer client [10]

\subsection{Squid}

Squid adalah high-performance proxy caching server untuk web klien, yang sudah mendukung FTP, ghoper dan objek data HTTP. Berbeda dengan software caching yang lama, suid menangani semua permintaan tunggal (single) nonblocking, I/O-driven process. Suid menyimpan meta data dan terutama hotobject yang disimpan di RAM, menyimpan DNS lookups, mendukung non-blocking DNS lookups, dan implementasi negative-caching jika permintaan gagal. Suid mendukung SSL, akses kontrol yang banyak dan full request logging. [11]

\section{a. Kelebihan Squid}


Proxy Server Squid mempunyai beberapa kelebihan, yaitu:

Bisa menghemat Bandwitch karena website yang pernah dikunjungi di simpan di cache proxy. Jika membuka halaman web yang sama, system akan mengecek dulu ke cache sebelum load ke server asli

Bisa melihat aktifitas User, berguna untuk mengawasi user yang melakukan aktifitas spamming

b. Kekurangan squid

Proxy Server Squid mempunyai kekurangan pula, yaitu :

Konfigurasi yang digunakan hanya beberapa tag-tag saja yang baru di implementasikan.

\section{METODE PENELITIAN}

Dalam penelitian ini, analisa dilakukan langsung dengan pihak $\mathrm{CV}$ Global Max. Analisa dilakukan dengan dua cara, yaitu dengan mengamati langsung keadaan yang ada sebelum proxy server dibangun dan dengan melakukan tanya jawab langsung dengan pihak-pihak terkait Dari dua kegiatan pada tahap analisa ini, akhirnya peneliti mengambil langkah-langkah yang perlu sehubungan dengan pengembang jaringan di CV Global Max, yaitu memperbaiki desain jaringan, membangun aturanaturan dalam proxy server, membangun proxy server dan memonitor kegiatan pengguna internet.

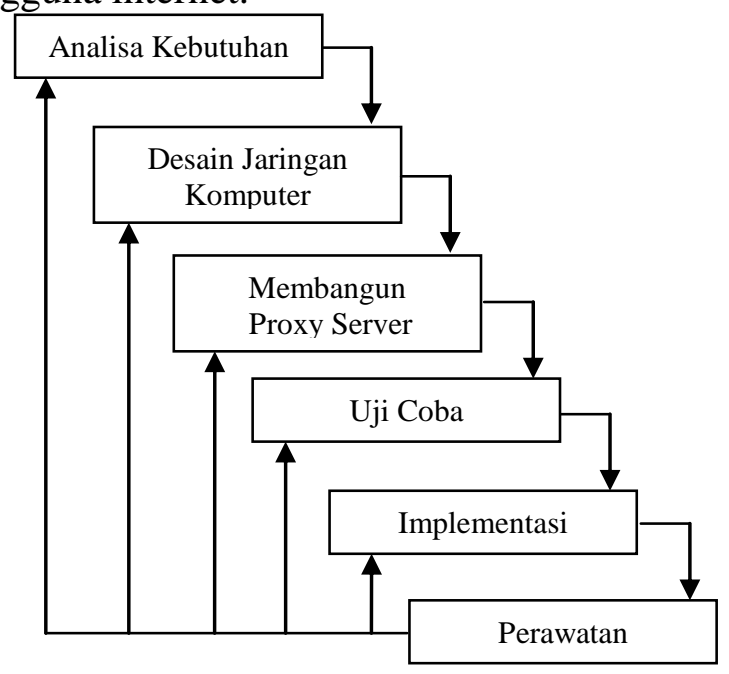

\section{Gambar 2. Metodologi Penyelesaian} Masalah

Desain jaringan komputer merupakan suatu kegiatan yang dilakukan oleh peneliti, dimana pada kegiatan ini peneliti melakukan pembangunan jaringan komputer di CV Global Max. Pada penelitian ini, pembangunan jaringan tidak dilakukan mulai dari Nol, tetapi hanya memperbaiki jaringan yang ada, karena sebelumnya telah dilakukan desain jaringan.

Pembangunan proxy server dilakukan peneliti mulai dari instalasi sistem operasi, dengan proxy server sampai dengan implementasi. Tahap selanjutnya adalah implementasi, pada tahapan ini setelah semua selesai maka peneliti melakukan implementasi desain proxy pada CV Global Max. Langkah akhir adalah melakukan perawatan terhadap jaringan dan akan dilakukan perubahan dimana letak kesalahan terjadi dan langsung diimplementasikan

\subsection{Tempat Penelitian}

Penelitian ini mengambil lokasi atau objek pada CV Global Max. Penelitian ini merupakan studi kasus tentang membangun proxy server menggunakan Sistem Operasi Linux BlankOn 6.0 Ombilin

\section{HASIL DAN PEMBAHASAN}

\section{Desain Jaringan}

Berdasarkan analisis kebutuhan untuk merancang / mengembangkan jaringan Proxy Server yang sesuai dengan kondisi minimum yang tersedia, berikut gambar perancangan jaringan lokal sederhana untuk pembuatan Proxy Server Squid 


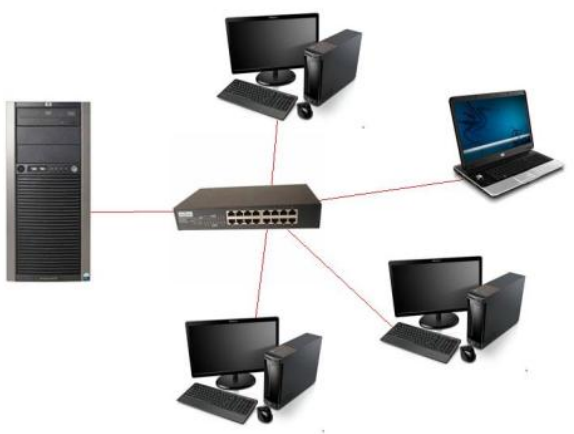

Gambar 3. Desain Jaringan Proxy server

Dapat dijelaskan, untuk pembuatan server proxy ini dibutuhkan server berbasis Linux BlankOn 6.0 Ombilin, dan digunakan IP Address kelas $\mathrm{C}$ yaitu 192.168.24.1. kemudian dari server tersebut disambungkan ke switch dan dilanjutkan ke beberapa komputer klien dengan IP Address dan Gateway yang disesuaikan dengan server, untuk klien digunakan OS windows XP, dan kabel yang digunakan untuk menyambungkan komputer server dengan switch 8 port dan komputer klien yaitu kabel straight, dengan menggunakan kabel UTP dan konektor RJ-45

\section{Prosedur Pengerjaan}

Dalam pembuatan jaringan server secara lokal, juga diperlukan managemen dalam persiapan dan alat-alat yang dibutuhkan dalam membuat suatu jaringan, berikut adalah identifikas kebutuhan yaitu:

\section{a. Komputer Server}

Untuk kebutuhan proxy server squid, perangkat minimal yang digunakan adalah :

Sistem Operasi : Linux BlankOn 6.0 Ombilin

Processor : Intel Atom 1.66

Ghz

Memory $\quad: 1024 \mathrm{Mb}$

Harddisk : $250 \mathrm{~GB}$

DVD room external

NIC internal

\section{b. Komputer Klien}

Untuk kebutuhan klien, perangkat minimal yang digunakan adalah :
Sistem Operasi : Windows 7

Processor : Pentium 4, 2.40

Ghz

Memory $\quad: 1024 \mathrm{Mb}$

Hardisk $\quad: 40 \mathrm{~Gb}$

NIC Internal

c. Kebutuhan lain

Switch 8 port

Kabel UTP \& RJ 45 secukupnya

$\mathrm{CD}$ installer Linux BlankOn 6.0

Ombilin'

CD Installer Windows 7

\section{Langkah-langkah Pengerjaan}

a. Instalasi Linux BlankOn 6.0

Ombilin

Di bawah ini merupakan diagram alur langkah-langkah instalasi Linux Blankon 6.0 Ombilin

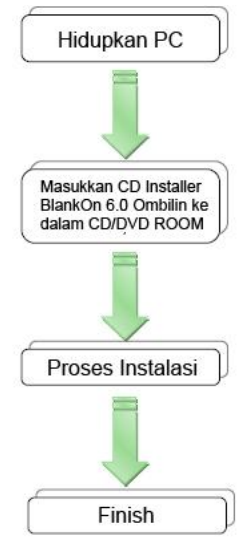

Gambar 4. Linux Blankon

\section{b. Instalasi dan konfigurasi paket aplikasi server \\ Di Bawah ini merupakan diagram} alur langkah-langkah instalasi dan konfigurasi aplikasi 


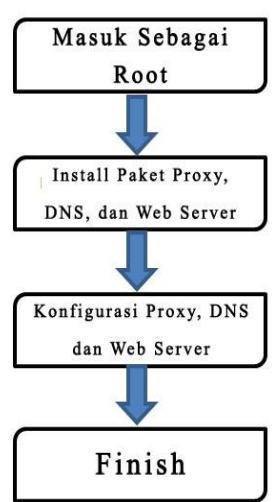

Gambar 5. Aplikasi Server

Langkah pertama yang harus dilakukan adalah masuk sebagai root dengan perintah :

\# sudo su

Langkah kedua adalah instalasi paket, bisa dilakukan dengan perintah :

\# dpkg -i nama_paket.deb

Langkah Ketiga adalah Konfigurasi file aplikasi. Dilakukan dengan mengetik sintak :

\# nano tempat_direktory/nama_file

Langkah terakhir adalah tahap finishing dengan merestart Operating System atau merestart aplikasi \# reboot

Atau

\# /etc/init.d/nama_service restart

\section{c. Konfigurasi Kabel UTP}

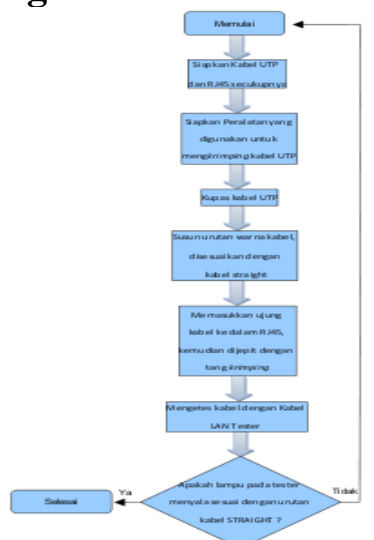

Gambar 6. Konfigurasi UTP

\section{Prosedur Pengujian}

Proxy squid server pada klien dapat digunakan setelah konfigurasi IP klien sama dengan IP Server, setelah itu buka web browser, kemudian coba ketikkan alamat yang diblokir / dns server

\section{Hasil desain Jaringan}

Untuk jaringan yang telah dibuat, minimal dibutuhkan 1 komputer server, switch 8 port (optional), 1 komputer klien, dan disambungkan dengan kabel UTP tipe straight. Berikut adalah jaringan Squid Proxy Server yang telah dibuat.

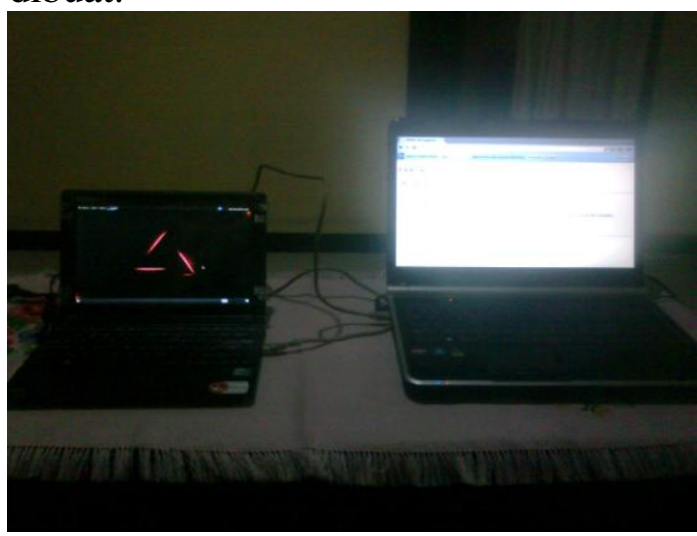

Gambar 7. Implementasi Jaringan Squid

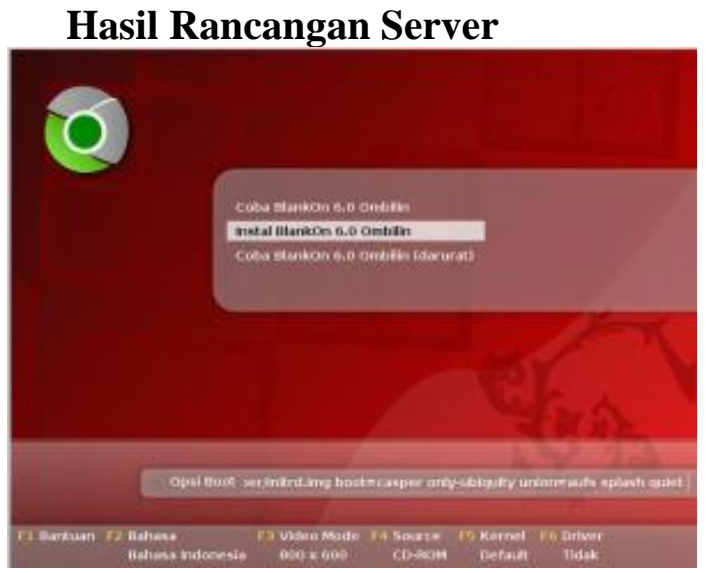

Gambar 8. Tampilan Utama Boot Linux BlankOn 6.0 Ombilin

\section{Konfigurasi pada Komputer Server}

Pada Instalasi Operating Sistem Linux BlankOn 6.0 Ombilin, ditentukan hostname menggunakan nama user, partisi dibagi menjadi 2 bagian, yaitu swap sebesar 2048 MB dan root sebesar $38 \mathrm{~GB}$, username yang digunakan pada awal login adalah user. 
Berikut merupakan tampilan dari hasil Instalasi Linux BlankOn 6.0 Ombilin

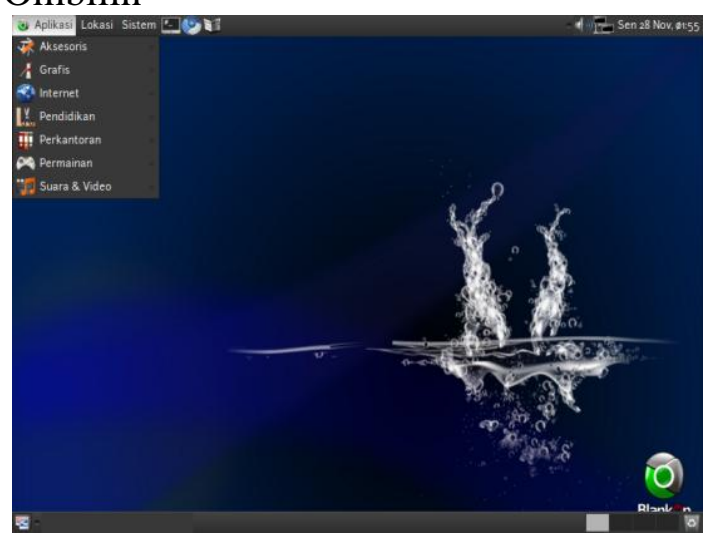

Gambar 9. Tampilan Hasil Instalasi Linux BlankOn 6.0 Ombilin

Konfigurasi utama yang harus dilakukan adalah memberikan IP pada server. Masuk ke Aplikasi $\rightarrow$ Aksesoris $\rightarrow$ Terminal untuk memulai proses konfigurasi :

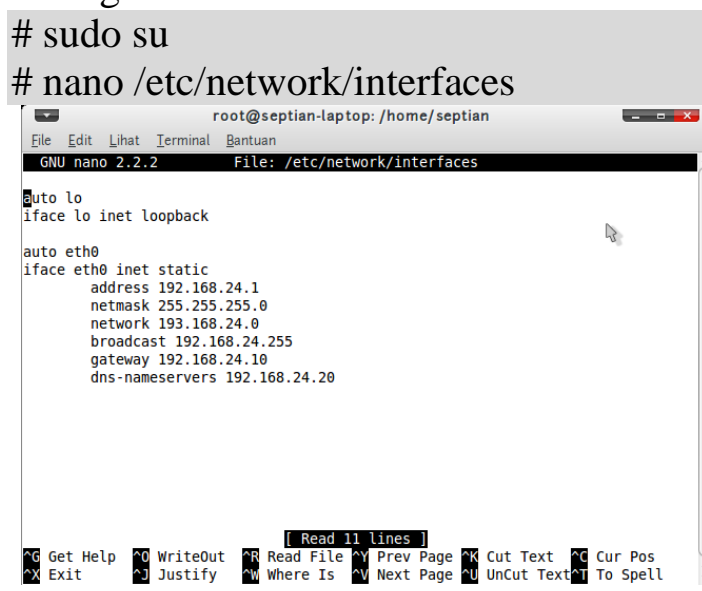

Gambar 10. Tampilan Konfigurasi IP Address

Simpan konfigurasi, dengan menekan tombol Ctrl X lalu tekan Y dan terakhir tekan Enter. Selanjutnya adalah merestart daemon networking \# /etc/init.d/networking restart

Uji hasil konfigurasi dengan perintah ping alamat_IP \# ping 192.168.24.1

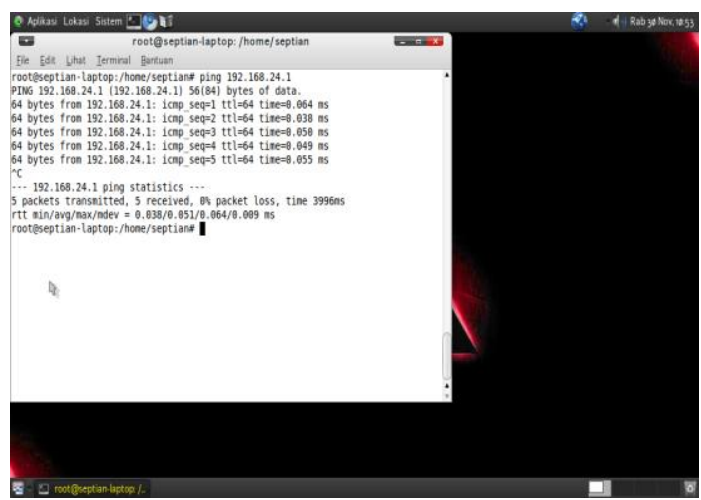

Gambar 11. Tampilan Hasil Pengujian IP

Apabila sudah muncul proses ping seperti gambar 4.16 maka konfigurasi berhasil, jika saat proses ping muncul tulisan 'Destination host unreachable' maka konfigurasi perlu dicek ulang

\subsection{Konfigurasi Klien}

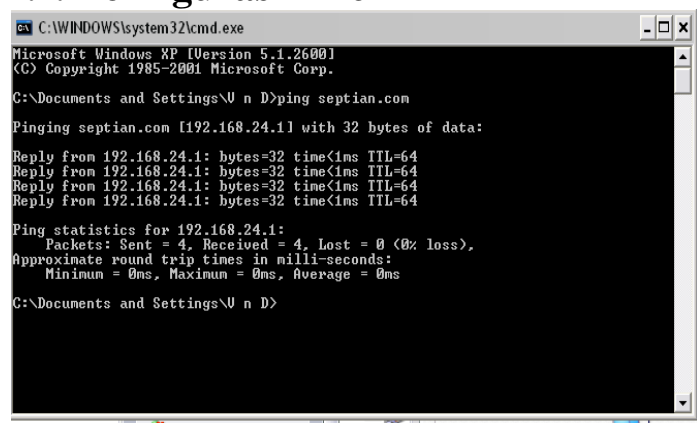

Gambar 12. Hasil Konfigurasi IP Address Komputer Klien

\subsection{Instalasi dan Pengujian Server}

\section{a. DNS Server Bind9}

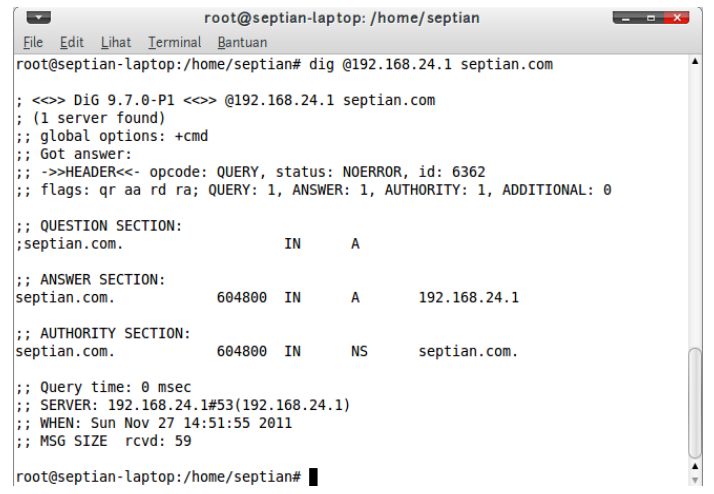

Gambar 13. Hasil Konfigurasi DNS

\section{b. Web Server Apache2}




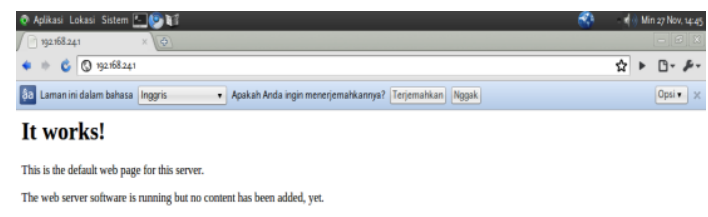

Gambar 14. Hasil pengujian web server

\section{c. Proxy Server Squid}

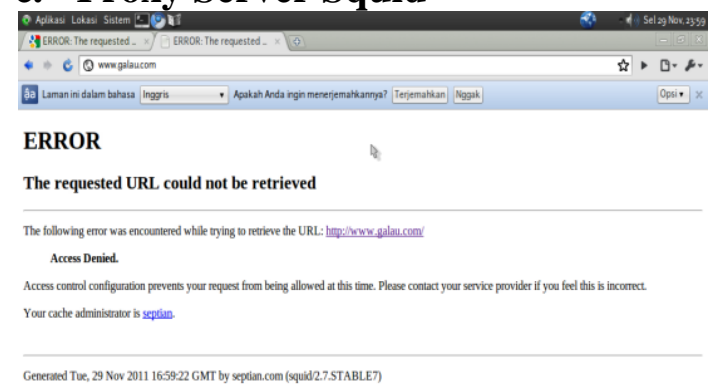

Gambar 15. Hasil akhir proxy server squid

\section{Hasil Pengujian}

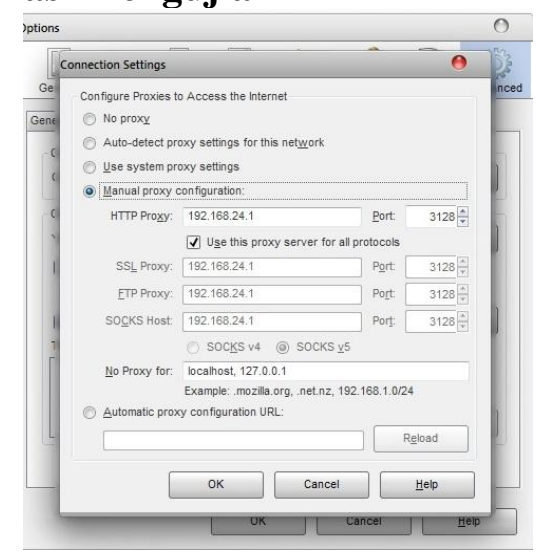

Gambar 16.Tampilan setting proxy di browser klien

Langkah terakhir adalah menuliskan alamat web yang diblokir di proxy server. Apabila muncul tulisan error seperti gambar 4.30 maka pengujian di klien telah berhasil

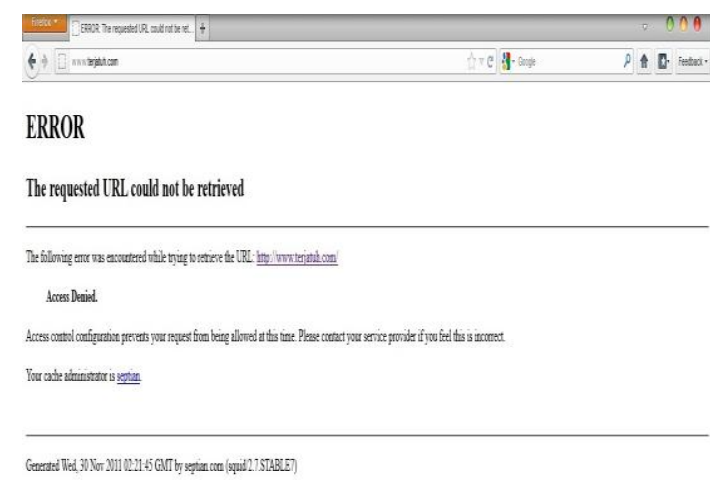

Gambar 17. Hasil pengujian proxy di klien

\section{KESIMPULAN}

Berdasarkan hasil penelitian dan pembahasan yang telah dilakukan dapat diambil kesimpulan bahwa :

a. Pada penelitian ini, kami telah mampu membanguan proxy server pada CV Global Max

b. Dengan menggunakan proxy server pada saat melakukan kegiatan internet dapat meminimalisasi serangan virus, worm, spyware dan DDOS

c. Manajemen jaringan dan lalu lintas internet Penghematan bandwidth dan peningkatan kecepatan dengan memanfaatkan Squid, sehingga mempersingkat waktu pengunduhan.

\section{REFERENSI}

Fatah Yasin Al Irsyadi, Implementasi Squid Server Pada Proxy Cache Video, Teknik Informatika Fakultas Komunikasi dan Informatika Universitas Muhammadiyah Surakarta, Jurnal Emitor ISSN 1411-8890, (2012).

Muawan,Samsul Mukhammad,. Implementasi Squid dan IP Table sebagai Proxy Server dan Firewall di Laboratorium Komputer SMK Negeri 1 Pogalan. Skripsi, Malang:Fakultas Teknik, Universitas Negeri Malang,( 2009) 
Yosike, , Kegunaan Proxy Server, http://yosike1706.blogspot.com/2010/01/keguna an-proxy-server.html, diakses 31 Agustus 2014, (2010)

Kasriyah, Makalah sistem operasi

BlankOn,http://kasriyah.blogspot.co $\mathrm{m} / 2012 / 09 /$ pengertian-osblankon.html diakses 31 Agustus 204, (2012)

Ward, Brian. How Linux Works; What every super-user should know. No Starch Press. 347 hlm, (2004).

Ma'sum ali, Zulfikri. Perancangan Linux Rouser sebagai PC Router. Teknik Informatika Fakultas Sains dan Teknologi UIN Syarif Hidayatullah Jakarta, (2011).

Harianto,http://pikopages.wordpress.com/ 2009/03/14/linux-yang-mana/ diakses 31 Agustus 2014, (2009)

Thanki Kunal U and Patel Chirag R, , Improve squid proxy's performance using new cache replacement architecture, International journal of management IT and Engineering, Vol.2 Issue 7, (2012).

http://www.microsoft.com/mspress/books /sampchap/4930b.aspx, diakses 2610-(2012).

Promilla and R.S. Chillar, Wi-fi security by using proxy server, International journal of computational engineering research, Vol.2 Issue 5, (2012).
Putra Candra adi. Pengembangan distribusi Linux Etix untuk lingkungan belajar Java. 97 $\operatorname{hlm}(2008)$.

